\title{
Effect of milk centrifugation and incorporation of high-heat-treated centrifugate on the composition, texture, and ripening characteristics of Maasdam cheese
}

\author{
Prabin Lamichhane, ${ }^{*} \dagger$ Alan L. Kelly, $†$ and Jeremiah J. Sheehan*1 \\ *Teagasc Food Research Centre, Moorepark, Fermoy, Co. Cork, Ireland P61 C996 \\ †School of Food and Nutritional Sciences, University College Cork, Cork, Ireland T12 YN60
}

\begin{abstract}
This study investigated the effect of centrifugation $\left(9,000 \times g, 50^{\circ} \mathrm{C}\right.$, flow rate $\left.=1,000 \mathrm{~L} / \mathrm{h}\right)$, as well as the incorporation of high-heat-treated (HHT) centrifugate into cheese milk on the composition, texture, and ripening characteristics of Maasdam cheese. Neither centrifugation nor incorporation of HHT centrifugate into cheese milk had a pronounced effect on the compositional parameters of any experimental cheeses, except for moisture and moisture in nonfat substance (MNFS) levels. Incorporation of HHT centrifugate at a rate of 6 to $10 \%$ of the total milk weight into centrifuged milk increased the level of denatured whey protein in the cheese milk and also increased the level of MNFS in the resultant cheese compared with cheeses made from centrifuged milk and control cheeses; moreover, cheese made from centrifuged milk had $\sim 3 \%$ higher moisture content on average than control cheeses. Centrifugation of cheese milk reduced the somatic cell count by $\sim 95 \%$ relative to the somatic cell count in raw milk. Neither centrifugation nor incorporation of HHT centrifugate into cheese milk had a significant effect on age-related changes in $\mathrm{pH}$, lactate content, and levels of primary and secondary proteolysis. However, the value for hardness was significantly lower for cheeses made from milk containing HHT centrifugate than for other experimental cheese types. Overall, centrifugation appeared to have little effect on composition, texture, and ripening characteristics of Maasdam cheese. However, care should be taken when incorporating HHT centrifugate into cheese milk, because such practices can influence the level of moisture, MNFS, and texture (particularly hardness) of resultant cheeses. Such differences may have the potential to influence subsequent eye development characteristic, although no definitive trends were observed in the present study and further research on this is recommended.
\end{abstract}

Received November 22, 2017.

Accepted February 27, 2018.

${ }^{1}$ Corresponding author: Diarmuid.Sheehan@teagasc.ie
Key words: centrifugation, heat-treatment, Maasdam cheese, texture, ripening characteristic

\section{INTRODUCTION}

Various milk pretreatment methods have been applied before cheesemaking to enhance quality, consistency, and functionality of different cheese varieties (Kelly et al., 2008; Johnson, 2017). Centrifugation of milk using a special centrifuge (also called Bactofuge, Alfa Laval, Richmond, VA) at a centrifugal force of $\sim 9,000 \times g\left(\right.$ at $\left.50^{\circ} \mathrm{C}\right)$ is a pretreatment method widely used by the cheese industry for removal of Clostridium spores before cheesemaking. After centrifugation, milk is divided into 2 streams, namely (1) centrifuged milk containing low bacterial cells and spores count, which account for $\sim 97 \%$ of the feed volume, and (2) centrifugate containing high bacterial cells and spores count, which account for $\sim 3 \%$ of the feed volume (Kosikowski and Mistry, 1990).

Some cheese producers apply high heat treatment to the centrifugate to inactivate bacterial cells and spores and recycle the stream back into centrifuged milk before cheesemaking to minimize protein losses, as it contains $\sim 7 \%$ protein (Kosikowski and Mistry, 1990). High heat treatment of milk results in denaturation of whey proteins (Rynne et al., 2004), which can form complexes with whey proteins (in the serum phase) and casein micelles (Donato and Guyomarc'h, 2009). Such complexes are believed to hinder the aggregation of destabilized casein micelles during rennet-induced coagulation of milk (Vasbinder et al., 2003), and thus reduce the ability of the gels to undergo syneresis, leading to cheese curd with higher levels of moisture and moisture in nonfat substance (MNFS). Moisture in the cheese matrix acts as a plasticizer between the protein strands and softens the cheese texture (Lamichhane et al., 2018a). Moreover, the higher moisture and MNFS content within the cheese matrix can enhance the microbial and enzymatic activities (Beresford et al., 2001), which can alter the ripening characteristics of cheese (Rynne et al., 2004, 2007). 
Some Clostridium spp. have been reported to be associated with late blowing defect of cheese, which is manifest as production of gas (e.g., $\mathrm{CO}_{2}$ and $\mathrm{H}_{2}$ ) and formation of high levels of butyric acid, resulting in downgraded cheeses (Klijn et al., 1995; Le Bourhis et al., 2007; Garde et al., 2011). Although the effect of centrifugation on efficacy of removal of Clostridium spores from milk and late blowing defect of cheese have been a research focus for several studies (Langeveld, 1971; Su and Ingham, 2000), its effect on composition, texture, and ripening characteristics of cheese has to date received little attention. As well as removal of Clostridium spores from milk, centrifugation also removes indigenous milk bacterial cells and somatic cells from milk by $\sim 87$ and 75 to $95 \%$ of the total count, respectively (Te Giffel and Van Der Horst, 2004; Wieking, 2004).

Maasdam is a brine-salted, large-eye forming, semihard cheese combining the traits of both Swiss and Dutch-type cheeses. Both lactic and citric acid fermentation occur during the first $24 \mathrm{~h}$ of manufacture and propionic acid fermentation occurs during warm-room ripening. Very little research has been published on the physicochemical properties and ripening characteristics of Maasdam and similar cheese types, such as Jarlsberg.

The aim of our study was to evaluate the effect of (1) centrifugation and (2) the incorporation of the high-heat-treated (HHT) centrifugate into cheese milk on the composition, $\mathrm{pH}$, primary and secondary proteolysis, lactic acids levels, and texture of Maasdam cheese during ripening. In our study, centrifugation refers to the separation of bacteria and spores at a centrifugal force of $\sim 9,000 \times g$ (at $50^{\circ} \mathrm{C}$ with a flow rate of $1,000 \mathrm{~L} / \mathrm{h}$ ), whereas centrifugal separation refers to separation of milk into cream and skim milk. A parallel study was conducted investigating the effect of milk centrifugation and incorporation of HHT centrifugate on microbial composition and the levels of volatile organic compounds of Maasdam cheese (Lamichhane et al., 2018b).

\section{MATERIALS AND METHODS}

\section{Milk Supply and Treatments}

Raw whole milk was obtained from a local dairy company. From raw milk, 3 different cheese milk streams were prepared (Figure 1). Part of the raw milk was separated at $55^{\circ} \mathrm{C}$ (centrifuge disc separator, GEA Westfalia, Oelde, Germany) to give skim milk and cream. Control cheese milk (CT) was prepared by adding a portion of the resultant cream to skim to achieve a protein-to-fat ratio of 1.13:1. The remaining whole milk was centrifuged (Bactofuge disc separator, type: D3187M, Alfa Laval, Richmond, VA) at a centrifugal force of $\sim 9,000 \times g$ (at $50^{\circ} \mathrm{C}$ with a flow rate of $1,000 \mathrm{~L} / \mathrm{h}$ ) to provide centrifuged whole milk and centrifugate (also called sludge or bactofugate), which accounts for approximately 3 to $6 \%$ of the total milk feed. Centrifuged whole milk was then separated to give skim and cream. Centrifuged cheese milk (CF) was prepared by adding portions of the cream into the skim milk to achieve a protein-to-fat ratio of 1.13:1. High heat treatment $\left(120^{\circ} \mathrm{C}\right.$ for $26 \mathrm{~s}$, plate heat exchanger, APV Schweig AG, Worb, Switzerland) was applied to centrifugate to inactivate spores and bacteria, and this centrifugate was combined with a portion of centrifuged cream and skim milk to produce the third cheese milk; that is, centrifuged milk containing HHT centrifugate (CFHHT). As the protein content of centrifugate after high heat treatment varied between 3.76 and $6.36 \%$ (wt/wt) between trials, HHT centrifugate was added to centrifuged milk on a protein basis rather than weight basis [i.e., approximately $12 \%$ (wt/wt) of the total protein was from HHT centrifugate in CFHHT milk; on weight basis, HHT centrifugate was added at a level of 6.6 to $10.3 \%$ (wt/wt), depending on the protein content of HHT centrifugate]. All cheese milk types (CT, CF, and CFHHT) were standardized to a protein-to-fat ratio of $\sim 1.13: 1$ and pasteurized $\left(72^{\circ} \mathrm{C}\right.$ for $\left.15 \mathrm{~s}\right)$ before cheese manufacture.

\section{Cheese Manufacture}

Three experimental Maasdam cheese types [i.e., cheese made from control milk (CT cheese), centrifuged milk (CF cheese), and centrifuged milk containing HHT centrifugate (CFHHT cheese)] were each manufactured on 3 different occasions in replicate cheesemaking trials over a 3 -mo period. Standardized and pasteurized cheese milks were pumped into cylindrical, jacketed cheese vats. Each vat contained automated variable speed cutting and stirring equipment (APV Schweig AG). All cheese milks (380 kg/vat) were inoculated at $31^{\circ} \mathrm{C}$ with frozen direct vat inoculate cultures (Chr. Hansen Ltd., Cork, Ireland), including (1) mixed strains of mesophilic bacteria (C950, $18 \mathrm{mg} /$ $\mathrm{kg}$ of milk), consisting of Lactococcus lactis ssp. cremoris, Lactococcus lactis ssp. lactis, and Leuconostoc; (2) Lactobacillus helveticus (LH-B01, $4.8 \mathrm{mg} / \mathrm{kg}$ of milk); and (3) propionic acid bacteria (PAB; PS-60, $7 \mathrm{mg} / \mathrm{kg}$ of milk). Calcium chloride (34\%, wt/vol) was added at a level of $0.3 \mathrm{~mL} / \mathrm{kg}$ of milk to each vat. Rennet (ChyMax Plus, 200 IMCU/mL; Chr. Hansen Ltd.), diluted $\sim 1: 10$ with deionized water, was added at a level of 0.2 $\mathrm{mL} / \mathrm{kg}$ of milk after a 40 -min ripening period at $31^{\circ} \mathrm{C}$. All gels were cut at a constant firmness (storage or elastic modulus, $\mathbf{G}^{\prime}$ ) value of $35 \mathrm{~Pa}$ (as measured using 
a small-amplitude oscillatory rheometer, AR 2000ex, TA Instruments, New Castle, DE), and the resultant curd particle/whey mixture was allowed to heal for 7 min before being stirred continuously for another 7 min. Stirring was then stopped and a portion of whey $(34 \mathrm{~kg} / 100 \mathrm{~kg}$ of cheese milk) was removed. After whey removal, reverse osmosis water at $\sim 50^{\circ} \mathrm{C}(23 \mathrm{~kg} / 100$ $\mathrm{kg}$ of cheese milk) was used to cook the curd to $37^{\circ} \mathrm{C}$ at a rate of $0.2^{\circ} \mathrm{C} / \mathrm{min}$ with continuous stirring. After the curd washing and cooking steps, whey and curd were drained into a prepress vat and curds were vertically prepressed under warm whey for $25 \mathrm{~min}$, with increasing pressure from 3 to $5 \mathrm{kPa}$. Whey was then drained from the prepress vat and the prepressed curd was subsequently cut into $10-\mathrm{kg}$ wheels (3 wheels from each vat), placed into $10-\mathrm{kg}$ molds, and pressed vertically under increasing pressure from 3.3 to $14 \mathrm{kPa}$ for $\sim 3.5 \mathrm{~h}$. When the $\mathrm{pH}$ of the cheese curds reached 5.49 to 5.51 , cheese wheels were transferred to a saturated brine solution ( $23 \%$ wt/wt $\mathrm{NaCl}, 0.56 \% \mathrm{CaCl}_{2}, \mathrm{pH} 5.2$, and $18^{\circ} \mathrm{C}$ ) for $24 \mathrm{~h}$. After brining, cheese wheels were vacuum-packed in $\mathrm{CO}_{2}$-permeable bags and transferred to the ripening room. The cheeses were ripened at $8^{\circ} \mathrm{C}$ for $10 \mathrm{~d}$ (preripening), at $23^{\circ} \mathrm{C}$ for $30 \mathrm{~d}$ (warm-room ripening), and finally stored at $4^{\circ} \mathrm{C}$ for $140 \mathrm{~d}$.

\section{Rennet Coagulation Properties}

In all 3 replicate cheesemaking trials, 2 min after rennet addition and stirring, a representative sample of milk was removed from the vat and placed into a cell of a small amplitude oscillatory rheometer (AR 2000ex, TA Instruments). A concentric-cylinder measuring geometry, consisting of a cylindrical bob and cup, was used. The dynamic changes in rheology during the coagulation process were monitored using a dynamic time sweep analysis with an angular frequency of $1.0 \mathrm{~Hz}$, and a strain of 0.01 at $31^{\circ} \mathrm{C}$, within the linear viscoelastic region (strain $<0.03$ ) reported for rennet milk gels (Mateo et al., 2010). Total time to reach a $\mathrm{G}^{\prime}$ value of gels of $35 \mathrm{~Pa}$ (at which cutting of the gel in the cheese vat was initiated) after rennet addition was calculated.

\section{Milk and Cheese Composition Analysis}

The composition of raw milk, centrifugate, and pasteurized cheese milks were analyzed using a Fourier transform infrared spectrophotometer (MilkoScan FT 120, Foss Electric, Hillerød, Denmark). Raw milk and centrifuged milk samples were analyzed for SCC (cells/ $\mathrm{mL}$ ) with a fluoro-opto-electronic counter (Fossomatic FC, Foss). Casein number, NPN, and levels of whey protein denaturation as percentage of total whey protein of HHT centrifugate and pasteurized cheese milk samples of 1 representative trial were determined as described by Rynne et al. (2004). Grated cheese samples were analyzed at $11 \mathrm{~d}$ at least in duplicate for moisture, fat, protein, salt, calcium, and $\mathrm{pH}$, as described by Sheehan et al. (2007a).

For determination of lactose and galactose content, cheese samples were extracted as described by Zeppa et al. (2001). Grated cheese samples (10 g) were mixed

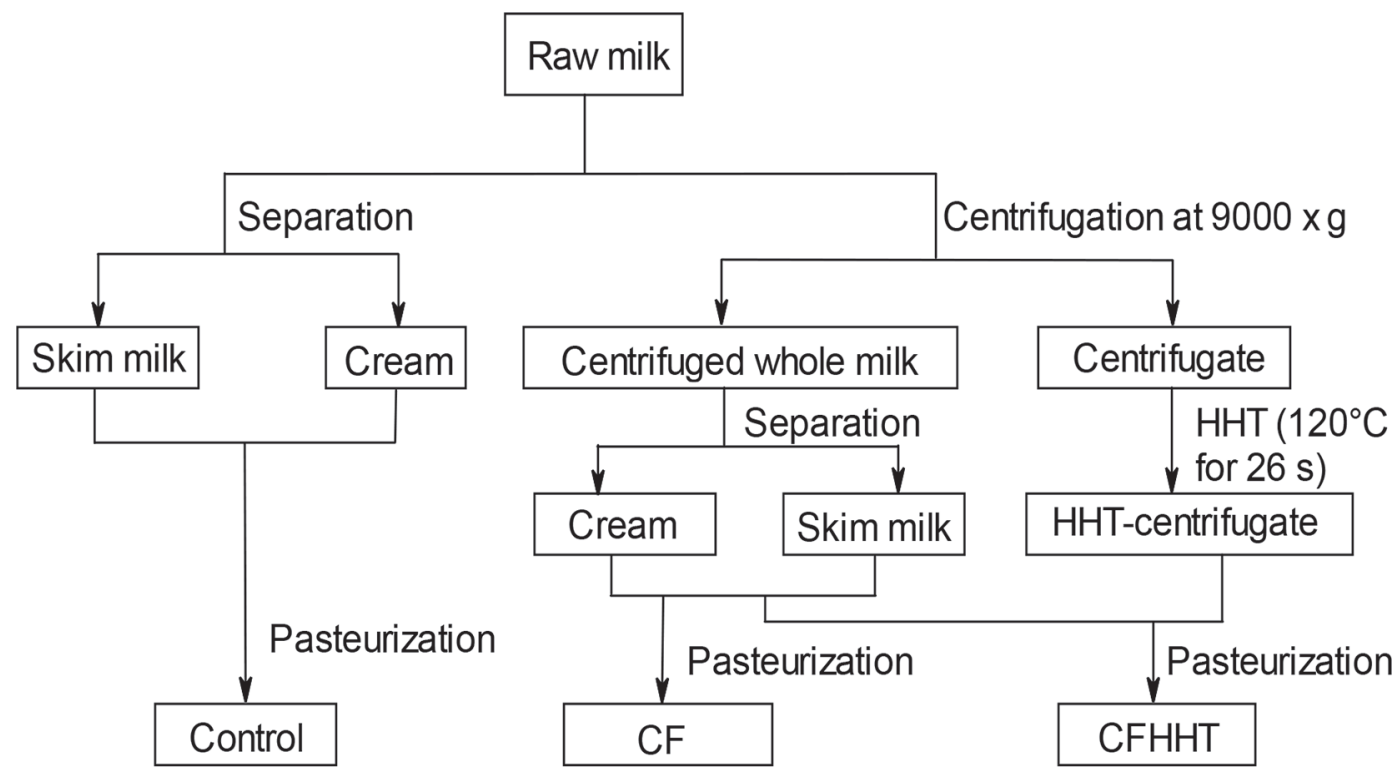

Figure 1. Flowcharts of the preparation of cheese milks [i.e., control, centrifuged (CF), and centrifuged milk containing high-heat-treated centrifugate $(\mathrm{CFHHT})]$. HHT $=$ high heat treatment; HHT-centrifugate $=$ high-heat-treated centrifugate. 
with $50 \mathrm{~mL}$ of $0.013 \mathrm{~N} \mathrm{H}_{2} \mathrm{SO}_{4}$ and stomached for $10 \mathrm{~min}$ using a stomacher (Iul Instruments, Barcelona, Spain) before centrifugation at $7000 \times g$ for $5 \mathrm{~min}$. The supernatant was then filtered using a $0.2-\mu \mathrm{m}$ nylon filter. The extracted samples were then analyzed by HPLC (Waters Alliance 2695 separation module, Waters, Milford, MA) with an Aminex HPX-87C Carbohydrate column $300 \times 7.8 \mathrm{~mm}$ (Bio-Rad, Hertfordshire, UK) under the following working conditions: injection volume of, $50 \mu \mathrm{L}$; mobile phase of $0.009 \mathrm{~N} \mathrm{H}_{2} \mathrm{SO}_{4}$; flow rate of $0.5 \mathrm{~mL} / \mathrm{min}$; column temperature of $60^{\circ} \mathrm{C}$; and refractive index detection (Waters 2414 RI detector). Quantification of lactose and galactose was based on the external standard method as described by Hou et al. (2014).

\section{SDS-PAGE Analysis}

The individual proteins in the raw milk, centrifugate before and after HHT, and cheese milks were identified by SDS-PAGE. All milk samples were diluted, using Milli-Q water (Millipore, Billerica, MA), to a protein concentration of $\sim 6 \mu \mathrm{g} / \mu \mathrm{L}$. A portion of the diluted samples were further diluted with SDS sample buffer [NuPAGE LDS Sample Buffer $(4 \times$; Thermo Fisher Scientific, Waltham, MA), composed of lithium salt, glycerine, sulfuric acid, and monododecyl ester]. For reducing SDS-PAGE, samples were treated with dithiothreitol [NuPAGE Sample Reducing Agent $(10 \times)$; concentration $=500 \mathrm{mmol} / \mathrm{L}]$ at a level of $10 \%(\mathrm{vol} /$ vol) of the total sample volume mixture. All samples were heated at $70^{\circ} \mathrm{C}$ for $10 \mathrm{~min}$, cooled, and loaded on SDS-PAGE gels (NuPAGE 12\% Bis-Tris mini gels) at a rate of $10 \mu \mathrm{g} /$ well before running in SDS running buffer [NuPAGE MOPS SDS Running Buffer $(1 \times)$ ] at constant voltage of $200 \mathrm{~V}$ for 50 min using Mini Gel Tank (XCell SureLock Mini, Thermo Fisher Scientific). After electrophoresis, the gels were stained as described by McCarthy et al. (2012). The SDS-PAGE gels were scanned using an Epson V700 film scanner (Epson, Suwa, Nagano, Japan). The identities of principal protein bands in the milk samples were determined using prestained protein molecular weight marker (PageRuler Prestained Protein Ladder, 10 to $180 \mathrm{kDa}$, Thermo Fisher Scientific).

\section{$p H$ and L- and D-Lactate Analysis}

The $\mathrm{pH}$ of cheese samples were measured on cheese slurry prepared by mixing $20 \mathrm{~g}$ of grated cheese and 12 $\mathrm{g}$ of deionized water at different time points throughout ripening (Sheehan et al., 2007a). The sample extraction method, as outlined for lactose and galactose content, was used for D- and L-lactic acid content determination. The extracted samples were analyzed for D- and L-lactic acid content using HPLC (Waters Alliance 2695 separation module) equipped with chiral column [Chirex 3126 (D)-penicillamine, column $150 \times 4.6 \mathrm{~mm}$, Phenomenex, Cheshire, UK], as described by Hou et al. (2014).

\section{pH 4.6-Soluble Nitrogen and Free Amino Acids}

The levels of $\mathrm{pH} 4.6$-soluble $\mathrm{N}$ (\% of total $\mathrm{N}$ ) and free amino acids (FAA) of the cheeses were measured after $1,11,41,65,97,140$, and $180 \mathrm{~d}$ as described by Fenelon and Guinee (2000) and Sheehan et al. (2007a), respectively.

\section{Texture Profile Analysis of Cheese}

Texture properties were analyzed by TAHDi texture profile analyzer (Stable Micro Systems, Goldalming, Surrey, UK), equipped with a 70-mm (diameter) compression plate and a $100-\mathrm{kg}$ load cell. Cheese was cut into 6 cube-shaped samples $\left(25 \mathrm{~mm}^{3}\right)$ using a Cheese Blocker (Bos Kaasgreedschap, Bodengraven, the Netherlands), wrapped in tin foil, and stored overnight at $4^{\circ} \mathrm{C}$. Cheese samples $\left(\sim 4^{\circ} \mathrm{C}\right)$ were compressed to $40 \%$ of their original height in 2 consecutive bites at a rate of $60 \mathrm{~mm} / \mathrm{min}$ (Henneberry et al., 2015). Texture profile analyzer parameters were calculated as previously described by Chevanan et al. (2006).

\section{Statistical Analysis}

Three experimental cheese types were each manufactured on 3 different occasions in replicate cheesemaking trials. An ANOVA, using IBM SPSS software version 24 (IBM Corp., 2016), was applied to determine the effect of treatment on milk and cheese composition. A split-plot design was used to determine the effects of treatments (centrifugation or addition of HHT centrifugate into cheese milk), ripening time, and their interactions on $\mathrm{pH}$, lactic acid-to-protein ratio, lactic acid, proteolysis, and texture. Analysis for the splitplot design was carried out using the PROC MIXED procedure of SAS software version 9.3 (SAS Institute Inc., 2011). Tukey's multiple-comparison test was used for paired comparison of treatment means at a $5 \%$ level of significance. IBM SPSS software version 24 (IBM Corp., 2016) was used to perform Pearson correlation between lactate-to-protein ratio and $\mathrm{pH}$. 
Table 1. Composition of centrifugate and pasteurized cheese milks ${ }^{1}$

\begin{tabular}{|c|c|c|c|c|c|}
\hline \multirow[b]{2}{*}{ Compositional parameter } & \multicolumn{2}{|c|}{ Centrifugate $^{2}$} & \multicolumn{3}{|c|}{ Cheese milk ${ }^{2}$} \\
\hline & Before HHT & After HHT & $\mathrm{CT}$ & $\mathrm{CF}$ & CFHHT \\
\hline$\overline{\text { Protein }(\%, \mathrm{wt} / \mathrm{wt})}$ & $6.10^{\mathrm{a}}$ & $5.11^{\mathrm{a}}$ & $3.38^{\mathrm{b}}$ & $3.29^{\mathrm{b}}$ & $3.32^{\mathrm{b}}$ \\
\hline Fat $(\%, w t / w t)$ & $0.23^{\mathrm{a}}$ & $0.22^{\mathrm{a}}$ & $2.98^{\mathrm{b}}$ & $2.90^{\mathrm{b}}$ & $2.92^{\mathrm{b}}$ \\
\hline Lactose $(\%, \mathrm{wt} / \mathrm{wt})$ & $4.52^{\mathrm{a}}$ & $4.05^{\mathrm{a}}$ & $4.74^{\mathrm{b}}$ & $4.66^{\mathrm{b}}$ & $4.64^{\mathrm{b}}$ \\
\hline Protein/fat & - & - & $1.134^{\mathrm{b}}$ & $1.135^{\mathrm{b}}$ & $1.137^{\mathrm{b}}$ \\
\hline Casein number & 79.22 & 89.72 & 79.56 & 79.16 & 80.69 \\
\hline NPN $(\%$, wt/wt) & 5.91 & 5.57 & 6.33 & 6.57 & 6.47 \\
\hline Native whey protein (\% of total) & 14.86 & 4.71 & 14.11 & 14.27 & 12.85 \\
\hline $\mathrm{WPD}^{3}$ (\% of total whey protein) & - & 68.30 & 5.81 & 4.77 & 14.24 \\
\hline
\end{tabular}

${ }^{a, b}$ Values within a row not sharing common superscripts differ $(P<0.05)$ in the case of protein, fat, lactose and protein/fat.

${ }^{1} \mathrm{HHT}=$ high heat treatment; $\mathrm{CT}=$ control milk; $\mathrm{CF}=$ centrifuged milk; CFHHT $=$ centrifuged milk containing high-heat-treated centrifugate.

${ }^{2}$ Data presented are the mean of data from 3 replicate trials for protein, fat, lactose, and protein/fat; for other parameters, data are from 1 representative trial. For parameters without superscripts, statistical analysis was not carried out because the data are from only 1 representative trial.

${ }^{3} \mathrm{WPD}=$ whey protein denaturation.

\section{RESULTS AND DISCUSSION}

\section{Raw Milk, Centrifugate, and Cheese Milk Composition}

The average fat, protein, and lactose contents of raw milk used for the 3 replicate cheesemaking trials were $4.01,3.41$, and $4.73 \%$ (wt/wt), respectively. Somatic cell counts of the raw milk between trials ranged between $1.2 \times 10^{5}$ and $2.4 \times 10^{5}$ cells $/ \mathrm{mL}$. The SCC of milk depends on factors such as breed and parity, stage of lactation, udder health, and also individual and environmental factors, as well as management practices $(\mathrm{Li}$ et al., 2017; Panthi et al., 2017). In general, the SCC of milk from healthy cows is less than $2 \times 10^{5}$ ( $\mathrm{Li}$ et al., $2014)$. The efficacy of centrifugation process $(9,000 \times$ $g$ at $50^{\circ} \mathrm{C}$ with a flow rate of $1,000 \mathrm{~L} / \mathrm{h}$ ) for removal of $\mathrm{SCC}$ was $\sim 95 \%$ relative to the SCC in raw milk, in close agreement with the study of Wieking (2004), who reported the efficacy of centrifugation as $\sim 95 \%$. It is generally accepted that the SCC of cheese milk negatively influences the cheese making and final cheese quality (Panthi et al., 2017). However, in contrast, a recent study (Li et al., 2017) suggested that the somatic cells have minimal effect per se on the cheesemaking and final cheese quality. This suggests that more research is needed to better understand the role of somatic cells in cheese quality.

The composition of centrifugate before and after HHT and cheese milks is shown in Table 1. The level of whey protein denaturation (WPD; as a percentage of total whey protein) in centrifugate after HHT was $68.30 \%$. It is widely recognized that HHT denatures whey proteins; for example, Rynne et al. (2004) observed that $34 \%$ of total whey protein was denatured when milk was heated at $87^{\circ} \mathrm{C}$ for $26 \mathrm{~s}$. The protein and lactose content of centrifugate decreased, although not significantly, after HHT. This is probably due to slight dilution with process flush water when utilizing a low volume of centrifugate $(\sim 40-45 \mathrm{~kg})$ in pilot-scale processing. Although fat, protein, and lactose contents of cheese milks were not statistically different, the level of WPD was $\sim 2.5$ - to 3-fold higher in CFHHT milk $(14.2 \%)$ than in CT $(5.8 \%)$ and CF $(4.8 \%)$ milks. The low level of WPD in CT and CF milk is attributed to pasteurization $\left(72^{\circ} \mathrm{C}\right.$ for $\left.15 \mathrm{~s}\right)$ of milk, whereas the level of WPD in CFHHT milk is attributed to both pasteurization and incorporation of HHT centrifugate. The level of WPD in pasteurized milk is in close agreement with that reported by Rynne et al. (2004).

\section{SDS-PAGE Analysis}

The individual proteins in raw milk, centrifugate before and after HHT, and cheese milks were analyzed using SDS-PAGE (Figure 2). The SDS-PAGE patterns of centrifugate before HHT were different compared with centrifugate after HHT, with a lower intensity of the bands corresponding to $\alpha-\mathrm{LA}, \beta-\mathrm{LG}$, and other minor proteins, such as lactoferrin and BSA, in HHT centrifugate. Moreover, some large protein aggregates were observed at the entry of stacking gel in the HHT centrifugate, as denoted by X in Figure 2A. Similar to our result, Patel et al. (2006) also observed heat-induced large aggregates in HHT milk samples. Heat-denatured whey proteins can form complexes with themselves and with caseins, particularly $\kappa_{-} \mathrm{CN}$, through disulfide interchange reactions and hydrophobic forces (Jean et al., 2006; Patel et al., 2006; Kethireddipalli and Hill, 

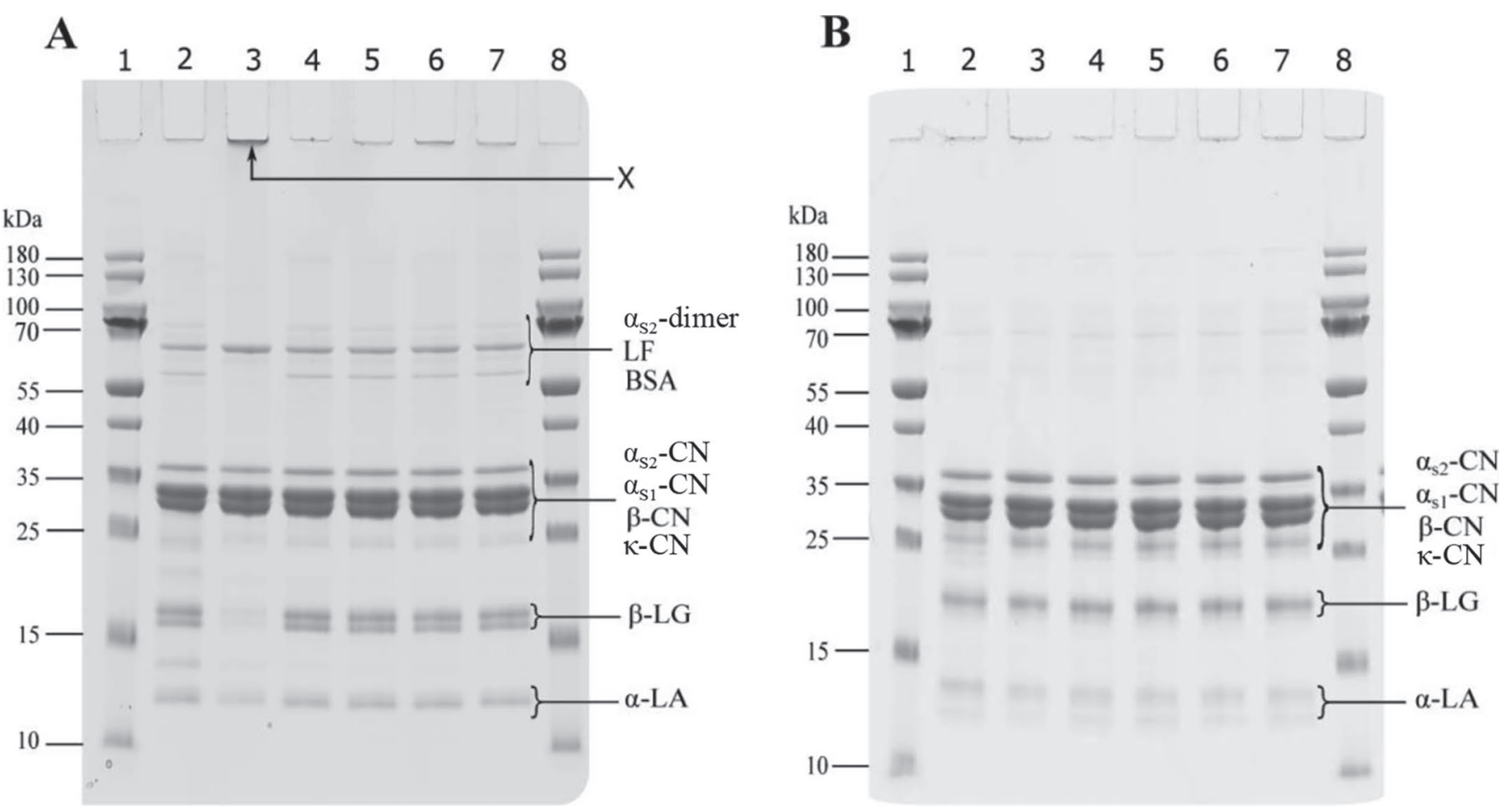

Figure 2. The SDS-PAGE patterns of milk samples under (A) nonreducing and (B) reducing conditions. Lane 1 and $8=$ prestained protein molecular weight marker; lane $2=$ centrifugate before high heat treatment; lane $3=$ centrifugate after high heat treatment; lane $4=$ raw milk; lane $5=$ pasteurized $\left(72^{\circ} \mathrm{C}\right.$ for $\left.15 \mathrm{~s}\right)$ control cheese milk; lane $6=$ pasteurized centrifuged milk containing high-heat-treated (HHT) centrifugate; and lane $7=$ pasteurized centrifuged milk. Protein aggregates in HHT centrifugate are denoted by X. LF $=$ lactoferrin. Samples shown are from 1 representative trial.

2015). In reducing SDS-PAGE, the large heat-induced aggregates in HHT centrifugate disappeared when the samples were reduced with dithiothreitol; moreover, the SDS-PAGE patterns in reduced gels appeared similar (Figure 2B). This suggests that the protein aggregates in HHT centrifugate may be bonded by various molecular forces, such as hydrophobic forces and disulfide bonding (Donato and Guyomarc'h, 2009).

The SDS-PAGE patterns of raw milk and cheese milks appeared similar, although the level of denatured whey protein was higher in cheese milks, especially CFHHT, than in raw milk. This suggests that the SDS-PAGE analysis is not very sensitive for differentiating between low levels of whey protein denaturation.

\section{Rennet Coagulation Characteristics}

The average time to reach an elastic shear modulus $\left(\mathrm{G}^{\prime}\right)$ value of $35 \mathrm{~Pa}$ for $\mathrm{CFHHT}, \mathrm{CT}$, and $\mathrm{CF}$ milks after rennet addition was $45.1,38.7$, and $40 \mathrm{~min}$, respectively. Several factors can influence the rennet-induced coagulation of milk, such as milk composition and renneting conditions (e.g., $\mathrm{pH}$, temperature, and ionic strength; Guinee et al., 2006; Ong et al., 2011, 2012).
Some studies have reported that the heat-induced complexes formed between whey protein and $\kappa-\mathrm{CN}$ on the surface of the casein micelles inhibit the primary phase of rennet coagulation (i.e., decrease the accessibility of enzyme to $\kappa-\mathrm{CN}$; Van Hooydonk et al., 1987). However, more recent studies have suggested that WPD has minimal effect on the primary phase of rennet coagulation; instead, WPD has a more clear effect on the secondary phase of rennet coagulation [i.e., aggregation (fusion) of destabilized casein micelles; Vasbinder et al., 2003]. The casein-whey protein and whey protein aggregates (in serum phase) can sterically hinder the aggregation of destabilized casein micelles (Waungana et al., 1996; Vasbinder et al., 2003). In the current study, although the level of denatured whey protein of CFHHT was $\sim 2.5$ - to 3-fold higher than that of CT and CF milks, the rennet coagulation time of CFHHT milk did not differ statistically significantly to the others. The levels of WPD (as a percent of total whey protein) for all experimental cheese milks were below $15 \%$, and it seems that such levels of WPD had no pronounced effect on the rennet-induced coagulation of milk. More pronounced effects were reported previously for severely heat-treated milk (Rynne et al., 2004). 
Table 2. Compositional parameters and $\mathrm{pH}$ at $11 \mathrm{~d}$ of ripening in Maasdam cheeses ${ }^{1}$

\begin{tabular}{|c|c|c|c|c|c|}
\hline \multirow[b]{2}{*}{ Compositional parameter $^{2}$} & \multicolumn{3}{|c|}{ Cheese type } & \multirow[b]{2}{*}{ SEM } & \multirow[b]{2}{*}{$P$-value } \\
\hline & $\mathrm{CT}$ & $\mathrm{CF}$ & CFHHT & & \\
\hline Moisture (\%,wt/wt) & $44.83^{\mathrm{a}}$ & $44.15^{\mathrm{a}}$ & $47.83^{\mathrm{a}}$ & 0.72 & 0.057 \\
\hline MNFS $(\%, w t / w t)$ & $58.9^{\mathrm{a}}$ & $58.14^{\mathrm{a}}$ & $61.78^{\mathrm{b}}$ & 0.63 & 0.013 \\
\hline Protein (\%, wt/wt) & $24.04^{\mathrm{a}}$ & $24.57^{\mathrm{a}}$ & $23.44^{\mathrm{a}}$ & 0.30 & 0.348 \\
\hline Fat $(\%, w t / w t)$ & $23.9^{\mathrm{a}}$ & $24.07^{\mathrm{a}}$ & $22.61^{\mathrm{a}}$ & 0.44 & 0.376 \\
\hline $\mathrm{FDM}(\%, w t / w t)$ & $43.31^{\mathrm{a}}$ & $43.07^{\mathrm{a}}$ & $43.29^{\mathrm{a}}$ & 0.35 & 0.966 \\
\hline Salt $(\%, w t / w t)$ & $1.53^{\mathrm{a}}$ & $1.50^{\mathrm{a}}$ & $1.73^{\mathrm{a}}$ & 0.05 & 0.183 \\
\hline $\mathrm{S} / \mathrm{M}(\%, \mathrm{wt} / \mathrm{wt})$ & $3.41^{\mathrm{a}}$ & $3.40^{\mathrm{a}}$ & $3.61^{\mathrm{a}}$ & 0.07 & 0.450 \\
\hline Total calcium (mg/100 g) & $821^{\mathrm{a}}$ & $800^{\mathrm{a}}$ & $837^{\mathrm{a}}$ & 12.19 & 0.514 \\
\hline $\mathrm{pH}(11 \mathrm{~d})$ & $5.28^{\mathrm{a}}$ & $5.31^{\mathrm{a}}$ & $5.27^{\mathrm{a}}$ & 0.01 & 0.548 \\
\hline \multicolumn{6}{|l|}{ Lactose $(\mathrm{mg} / 100 \mathrm{~g})$} \\
\hline $1 \mathrm{~d}$ & $54.39^{\mathrm{a}}$ & $41.82^{\mathrm{a}}$ & $66.72^{\mathrm{a}}$ & 16.26 & 0.861 \\
\hline $11 \mathrm{~d}$ & $20.42^{\mathrm{a}}$ & $43.72^{\mathrm{a}}$ & $62.63^{\mathrm{a}}$ & 15.07 & 0.585 \\
\hline $41 \mathrm{~d}$ & $0.00^{\mathrm{a}}$ & $0.00^{\mathrm{a}}$ & $0.00^{\mathrm{a}}$ & 0.00 & - \\
\hline \multicolumn{6}{|l|}{ Galactose $(\mathrm{mg} / 100 \mathrm{~g})$} \\
\hline $1 \mathrm{~d}$ & $28.09^{\mathrm{a}}$ & $29.57^{\mathrm{a}}$ & $35.34^{\mathrm{a}}$ & 4.11 & 0.798 \\
\hline $11 \mathrm{~d}$ & $27.61^{\mathrm{a}}$ & $27.26^{\mathrm{a}}$ & $30.82^{\mathrm{a}}$ & 4.22 & 0.947 \\
\hline $41 \mathrm{~d}$ & $0.00^{\mathrm{a}}$ & $0.00^{\mathrm{a}}$ & $0.00^{\mathrm{a}}$ & 0.00 & - \\
\hline
\end{tabular}

\section{Cheese Composition}

The composition of the experimental cheeses is shown in Table 2. Centrifugation of milk had no significant effect on mean levels of moisture, MNFS, protein, fat, salt, total calcium, lactose, and galactose of final cheeses. However, incorporation of HHT centrifugate into the centrifuged milk increased $(P<0.05)$ the mean levels of MNFS of the resultant cheeses. The average moisture content of CFHHT cheese was $\sim 3 \%$ higher than control and CF cheeses, which was expected and sizeable in magnitude for cheese moisture; however, the difference was not statistically significant $(P=0.057)$. This is explained by a degree of variation in the compositional data between trials, which influenced the statistical analysis of the data. The coefficients of variation of average moisture content of the experimental cheeses between 3 trials were below $5 \%$, which is considered acceptable (Thomsson et al., 2014). Higher moisture and MNFS levels in CFHHT cheeses are partly attributed to the negative effect of HHT centrifugate on syneresis (expulsion of whey) of rennet-induced milk gels. Denatured whey protein present in HHT centrifugate can sterically hinder the aggregation (fusion) of destabilized casein micelles, as described before, and thus hinders syneresis (Pearse et al., 1985; Walstra et al., 1985; Vasbinder et al., 2003). Moreover, the high water-binding capacity of the denatured whey proteins may increase the level of MNFS in the CFHHT cheeses (Donato and Guyomarc'h, 2009). These results are in agreement with the results of Guinee et al. (1998) and Rynne et al. (2004), who observed increased moisture and MNFS of Cheddar cheese with increasing levels of denatured whey protein.

Some studies also observed a decrease in the level of total calcium in cheese made from HHT milk (Guinee et al., 1998); however, such results were not observed in the current study. The mean levels of lactose and galactose were very low, below $\sim 67$ and $\sim 36 \mathrm{mg} / 100 \mathrm{~g}$ of cheese, respectively, until $11 \mathrm{~d}$ of ripening, and lactose and galactose were not detected after warm-room ripening (Table 2). Low lactose and galactose contents within this cheese type were expected, as the lactose contents of cheese curd were reduced by curd washing.

\section{Age-Related Changes in $\mathrm{pH}$}

The $\mathrm{pH}$ of all experimental cheeses increased $(P<$ 0.001 ) over the $180 \mathrm{~d}$ of ripening (Figure $3 \mathrm{~A}$, Table 3) from a mean value of $\sim 5.2$ at $1 \mathrm{~d}$ to $\sim 5.7$ at $180 \mathrm{~d}$. This trend is in agreement with that reported in a previous study of Gouda cheese by Lawrence et al. (1987), who also observed an increase in $\mathrm{pH}$ from $\sim 5.15$ at $1 \mathrm{~d}$ to $\sim 5.5$ to 5.9 at $150 \mathrm{~d}$ of ripening. The increase in the $\mathrm{pH}$ is attributed to several factors, including the proteolytic liberation of basic compounds, such as ammonia, free basic AA, and amines (Fenelon and Guinee, 2000; McSweeney, 2004). A reduction in lactate-to-protein ratio during maturation of cheese (Figure 3B) is known to increase the buffering capacity of cheese (Sheehan 
et al., 2007a), which may contribute to some extent to the increase in cheese $\mathrm{pH}$ during ripening. The $\mathrm{pH}$ of the cheese curd was significantly $(P<0.001)$ negatively correlated (adjusted $\mathrm{R}^{2}=0.53$ ) with lactate-to-protein ratio (Figure 3C).

In some brine-salted cheese types, such as Gouda, Edam, and Maasdam, the $\mathrm{pH}$ after brining is controlled by adjusting the residual curd lactose content by techniques such as curd washing or whey dilution (Lawrence et al., 1987). More recently, membrane separation techniques, such as ultrafiltration, have also been used for standardization of lactose content of cheese milk before cheesemaking (Moynihan et al., 2016 ). In the present study, $\sim 34 \%$ (wt/wt) of whey was replaced with $\sim 23 \%$ (wt/wt) warm reverse-osmosis water to control the postmanufacture reduction of pH. In contrast, O'Sullivan et al. (2016) observed a decrease in $\mathrm{pH}$ at the early stages of ripening in Swisstype cheese (where whey was not replaced by warm water $)$; however, the postbrining $\mathrm{pH}$ was higher $(\sim 5.6)$ than that of the cheese in the current study $(\sim 5.3)$. The decrease in the $\mathrm{pH}$ at the early stages of ripening has been attributed to continual metabolism of residual lactose and galactose to lactate by starter and nonstarter lactic acid bacteria (NSLAB; O'Sullivan et al., 2016). Shakeel-Ur-Rehman et al. (2004) also observed a decrease in the $\mathrm{pH}$ during ripening when Cheddar cheese was made from milk supplemented with lactose. Regulation of $\mathrm{pH}$ is critical for proper eye development in some eye-forming cheese types, and a reduction in $\mathrm{pH}$ can reduce the levels of colloidal calcium, which are considered essential for elastic texture of cheese (Lucey and Fox, 1993), and inhibit the growth of PAB (Sheehan et al., 2008). Elastic texture is important in the case of eye-forming cheese types to accommodate gas produced during warm-room ripening for smooth eye formation (Daly et al., 2010). No significant effect of treatment on the mean cheese $\mathrm{pH}$ during maturation was observed (Table 3).

\section{Levels of L-, D- and Total Lactate}

The mean level of L-lactate of all experimental cheeses was $\sim 1.5 \%$ (wt/wt) until $11 \mathrm{~d}$ of ripening, which is most likely due to fermentation of glucose, lactose, and galactose by starter lactic acid bacteria, including Lactococcus lactis ssp. cremoris, Lactococcus lactis ssp. lactis, and Lactobacillus helveticus, during production of cheese (Beresford et al., 2001). However, the level of L-lactate decreased $(P<0.001)$ over ripening in all experimental cheeses, especially during warm room ripening from a mean of $\sim 1.5 \%$ (wt/wt) at 11 $\mathrm{d}$ to $\sim 0.4 \%$ (wt/wt) at $41 \mathrm{~d}$ (Figure $4 \mathrm{~A}$ ). This trend is in agreement with that reported in previous studies
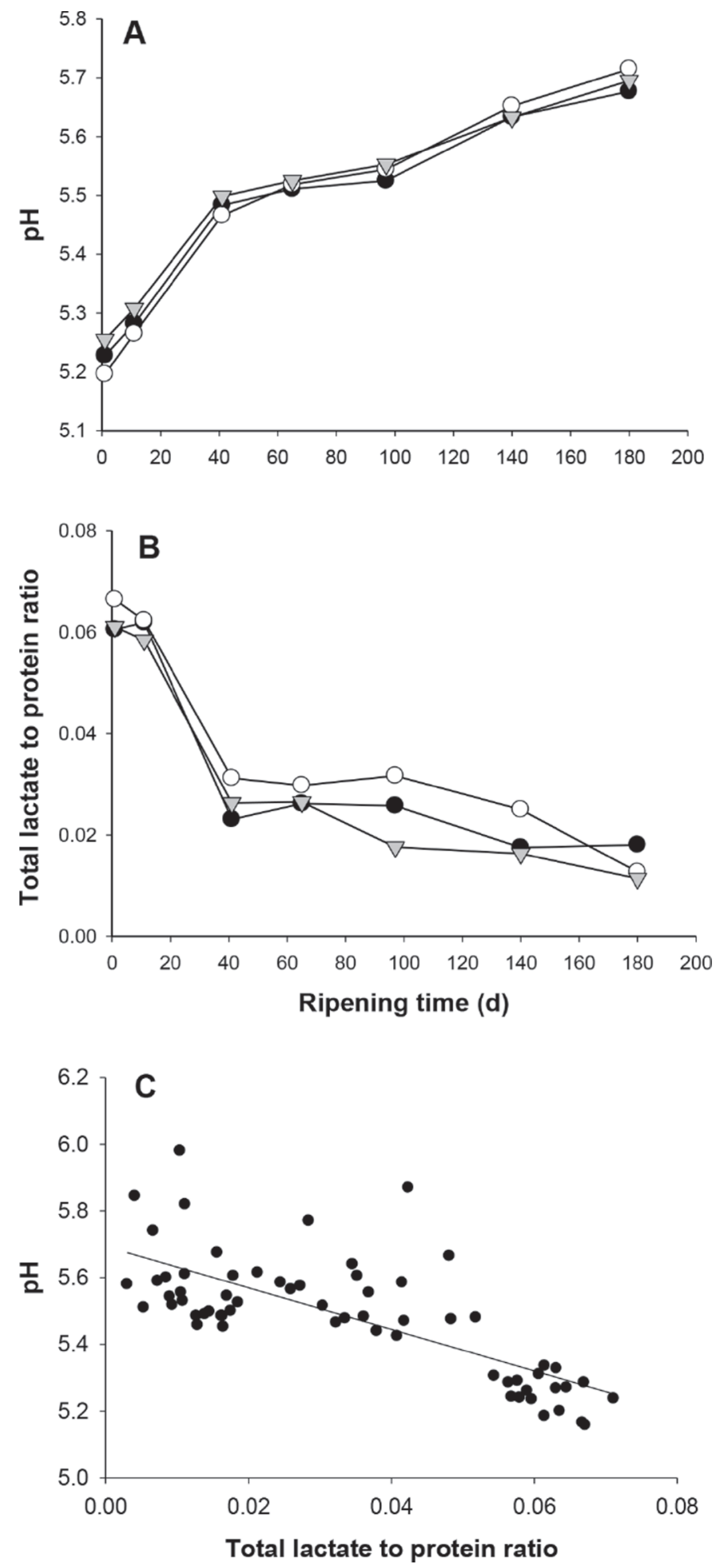

Figure 3. The effect of milk pretreatments on (A) $\mathrm{pH}$ and (B) lactate to protein ratio of Maasdam cheese during maturation. Milk pretreatments were control $(\mathbf{\bullet})$; centrifugation $(\mathbf{v})$; and centrifuged milk containing high-heat-treated centrifugate $(\mathrm{O})$. Data presented are means of data from 3 replicate trials. (C) Relationship between $\mathrm{pH}$ and lactate-to-protein ratio; data were obtained from all experimental cheeses produced in 3 replicate trials and analyzed over a $180 \mathrm{~d}$ of ripening. 
Table 3. Summary of the effects of treatment, time, and their interactions on properties of Maasdam cheeses ${ }^{1}$

\begin{tabular}{lccc}
\hline Parameter $^{2}$ & Treatment & Time & $\begin{array}{c}\text { Interactive effect } \\
\text { (treatment } \times \text { time) }\end{array}$ \\
\hline pH & NS $(0.81)$ & $* * *$ & NS $(1.00)$ \\
Total lactate-to-protein ratio & NS $(0.33)$ & $* * *$ & NS $(0.99)$ \\
L-Lactate & NS $(0.70)$ & $* * *$ & NS $(0.99)$ \\
D-Lactate & NS $(0.32)$ & $* * *$ & NS $(0.99)$ \\
Total lactate & NS $(0.53)$ & $* * *$ & NS $(0.99)$ \\
pH 4.6-SN $(\% \mathrm{TN})$ & NS $(0.65)$ & $* * *$ & NS $(1.00)$ \\
Total FAA & NS (0.74) & $* * *$ & NS $(0.96)$ \\
Hardness & NS $(0.97)$ \\
Springiness & NS $(0.71)$ & NS $(0.29)$ & NS $(0.40)$ \\
Cohesiveness & NS (0.08) & $* * *$ & NS $(0.57)$ \\
Resilience & NS $(1.00)$ & $* *$ & NS $(0.96)$ \\
\hline
\end{tabular}

${ }^{1}$ Digits in parentheses after NS represent $P$-value.

${ }^{2} \mathrm{pH} 4.6-\mathrm{SN}(\% \mathrm{TN})=$ soluble nitrogen at $\mathrm{pH} 4.6$ as percentage of total nitrogen; FAA $=$ free AA.

${ }^{*} P<0.05,{ }^{* *} P<0.01,{ }^{* * *} P<0.001, \mathrm{NS}=P>0.05$.

for different cheese varieties, such as Swiss-style cheese (Sheehan et al., 2008; O’Sullivan et al., 2016), Grevé (eye-forming, semihard cheese types; Rehn et al., 2011), and Cheddar (Rynne et al., 2007). This was expected, as L-lactate is metabolized by starter and nonstarter bacteria to different metabolites, such as propionate, acetate, butyrate, formate, succinate, DL-lactate, $\mathrm{CO}_{2}$, $\mathrm{H}_{2}$, and $\mathrm{H}_{2} \mathrm{O}$ (McSweeney, 2004; Agarwal et al., 2006).

D-Lactate was virtually absent for all experimental cheeses at 1 and $11 \mathrm{~d}$ of ripening. However, unlike Llactate, the level of D-lactate increased $(P<0.001)$ during warm room ripening, from a mean of $\sim 0.01 \%$ (wt/wt) at $11 \mathrm{~d}$ to $\sim 0.2$ to $0.3 \%$ (wt/wt) at $41 \mathrm{~d}$ (Figure 4B). D-Lactate within cheese matrix typically arises either from fermentation of glucose, lactose, or galactose by microorganisms, including Lactobacillus helveticus and some Leuconostoc spp. (Beresford et al., 2001), or by racemization of L-lactate by NSLAB (Agarwal et al., 2006). As the levels of residual lactose and galactose were very low in all experimental cheeses before warm-room ripening (below 70 and $40 \mathrm{mg} / 100 \mathrm{~g}$, respectively) due to curd washing, it may be assumed that the contribution of residual lactose and galactose for formation of D-lactate is minimal. The formation of D-lactate is most likely due to racemization of $\mathrm{L}$ lactate to DL-lactate by NSLAB because the level of NSLAB reached $\sim 10^{8} \mathrm{cfu} / \mathrm{g}$ in all cheeses at $41 \mathrm{~d}$ of ripening (data not shown). Similar trends have previously been reported in different cheese varieties, such as half-fat Cheddar (Rynne et al., 2007) and Swiss-type cheese (O'Sullivan et al., 2016). Interestingly, the level of D-lactate decreased gradually after $65 \mathrm{~d}$ of ripening, probably due to its metabolism by microorganisms within the cheese matrix such as PAB (O'Sullivan et al., 2016). The degradation pathways of D-lactate in the cheese matrix are not yet fully understood. No sig- nificant effect of treatment was observed in the levels of L-lactate, D-lactate, and total lactate (Figure 4C) throughout ripening (Table 3 ).

\section{Proteolysis}

Nitrogen Soluble at $p H$ 4.6. Primary proteolysis in cheeses was assessed by measuring the level of nitrogen soluble at $\mathrm{pH} 4.6$, as a percentage of total nitrogen, which increased $(P<0.001)$ in all cheeses over the 180 d of ripening, especially during warm-room ripening, from $\sim 5 \%$ of total nitrogen before warm-room ripening $(11 \mathrm{~d})$ to $\sim 17 \%$ of total nitrogen at the end of warm-room ripening $(41 \mathrm{~d})$ in all experimental cheeses (Figure 5A). The levels in all cheeses reached $\sim 22 \%$ at $180 \mathrm{~d}$. The increase was of the same order of magnitude as that previously reported for semihard cheeses (Exterkate and Alting, 1995; Sheehan et al., 2007b; Huc et al., 2014). However, no significant effect of treatment on level of nitrogen soluble at $\mathrm{pH} 4.6$, as a percentage of total nitrogen was observed (Table 3 ).

Total and Individual FAA. The mean levels of total FAA increased $(P<0.001)$ during ripening, especially when the cheeses entered the hot-room ripening phase, from $\sim 3,000 \mathrm{mg} / \mathrm{kg}$ at $11 \mathrm{~d}$ to $\sim 7,000$ to 8,000 $\mathrm{mg} / \mathrm{kg}$ at $41 \mathrm{~d}$ (Figure $5 \mathrm{~B}$ ). Enzymes from starter and nonstarter microorganisms and somatic cells, such as proteases and peptidases, contribute to primary and secondary proteolysis where present within the cheese matrix, and thereby to liberation of FAA during ripening (McSweeney, 2004; Kelly et al., 2006). No significant effect of treatment was observed (Table 3), although it was expected that the centrifugation process could alter secondary proteolysis, as the process can remove $\sim 86$ to $92 \%$ of total indigenous bacteria and $\sim 95 \%$ of somatic cells from cheese milk (Te Giffel and Van Der 

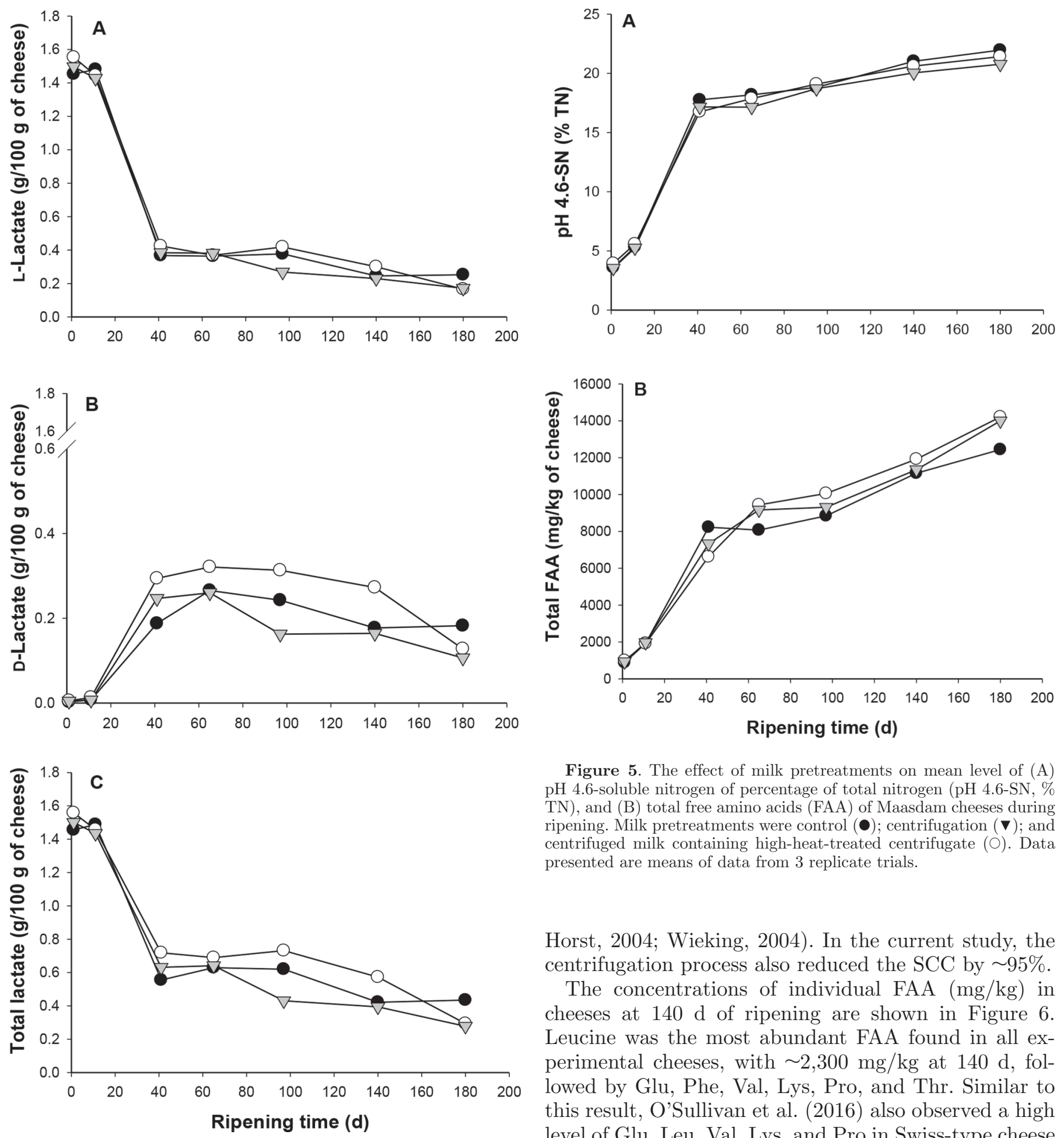

Figure 4. The effect of milk pretreatments on the mean level of (A) L-lactate, (B) D-lactate, and (C) total lactate of Maasdam cheeses during ripening. Milk pretreatments were control (๑); centrifugation $(\boldsymbol{\nabla})$; and centrifuged milk containing high-heat-treated centrifugate (○). Data presented are means of data from 3 replicate trials.

Figure 5. The effect of milk pretreatments on mean level of (A) $\mathrm{pH}$ 4.6-soluble nitrogen of percentage of total nitrogen ( $\mathrm{pH}$ 4.6-SN, \% $\mathrm{TN}$ ), and (B) total free amino acids (FAA) of Maasdam cheeses during ripening. Milk pretreatments were control $(\mathbf{\bullet})$; centrifugation $(\mathbf{v})$; and centrifuged milk containing high-heat-treated centrifugate $(\bigcirc)$. Data presented are means of data from 3 replicate trials.

Horst, 2004; Wieking, 2004). In the current study, the centrifugation process also reduced the SCC by $\sim 95 \%$.

The concentrations of individual FAA $(\mathrm{mg} / \mathrm{kg})$ in cheeses at $140 \mathrm{~d}$ of ripening are shown in Figure 6. Leucine was the most abundant FAA found in all experimental cheeses, with $\sim 2,300 \mathrm{mg} / \mathrm{kg}$ at $140 \mathrm{~d}$, followed by Glu, Phe, Val, Lys, Pro, and Thr. Similar to this result, O'Sullivan et al. (2016) also observed a high level of Glu, Leu, Val, Lys, and Pro in Swiss-type cheese at $95 \mathrm{~d}$ of ripening. In contrast, the concentrations of Asp, Ser, Gly, Cys, Tyr, and Arg were among the lowest of the FAA. Free AA are important precursors for the formation of different classes of volatiles, such as amines, aldehydes, alcohols, acids, and sulfur compounds (Engels et al., 1997; Yvon and Rijnen, 2001). 


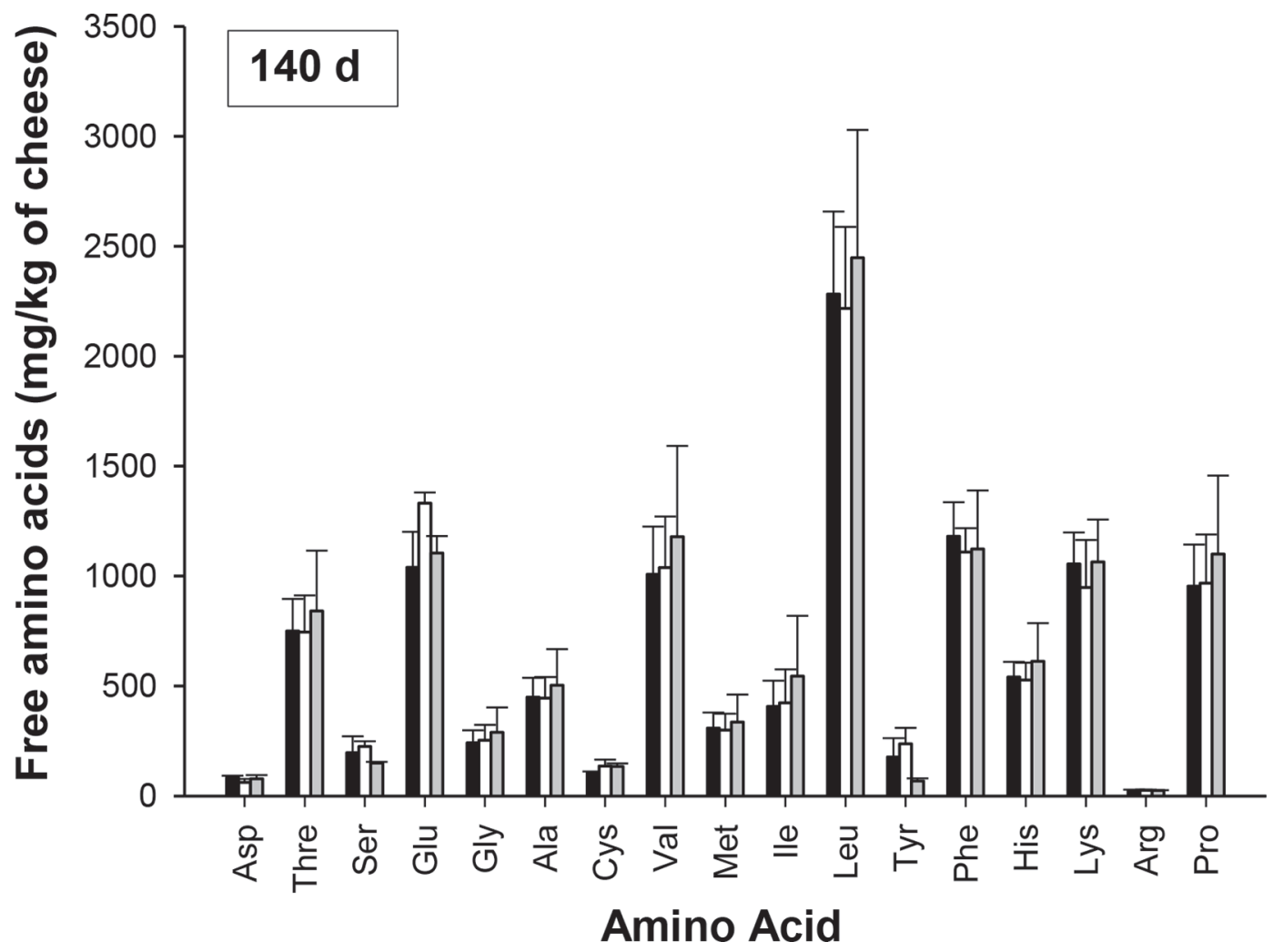

Figure 6. The effect of milk pretreatments on the mean levels of individual free AA in $\mathrm{pH}$ 4.6-soluble nitrogen extracts from Maasdam cheeses at $140 \mathrm{~d}$ of ripening. Milk pretreatments were control (black bars), centrifugation (white bars); and centrifuged milk containing highheat-treated centrifugate (gray bars). Data presented are means of data from 3 replicate trials. Error bars show the SEM from 3 replicate trials.

No significant effect of treatment on the mean levels of individual FAA at $140 \mathrm{~d}$ of ripening was observed.

\section{Texture Profile Analysis}

The incorporation of HHT centrifugate into cheese milk decreased $(P<0.05)$ the mean level of instrumentally measured hardness of the resultant cheeses compared with $\mathrm{CT}$ and $\mathrm{CF}$ cheeses (Figure 7). This was attributed to significantly higher MNFS level in the CFHHT cheeses than CT and CF cheeses; MNFS is considered a good indicator of moisture associated with proteins (Lawrence et al., 1993). Moisture in the cheese matrix acts as a plasticizer between the protein strands, making cheese softer and more flexible. Moreover, during coagulation, the whey protein and whey protein-casein micelle aggregates may hinder the close approach of casein micelles during aggregation (fusion) of destabilized casein micelles; this may result in a weaker gel and curd texture (Waungana et al., 1996). From a materials science perspective, the strength of a material is known to be influenced by factors such as the extent of cross-linking and the orientation or the structural regularity of the constituents of the mate- rial (Pastorino et al., 2003; Lamichhane et al., 2018a). It may be assumed that denatured whey protein can alter the extent of cross-linking of casein micelles and the orientation or the structural regularity of casein networks within the cheese matrix.

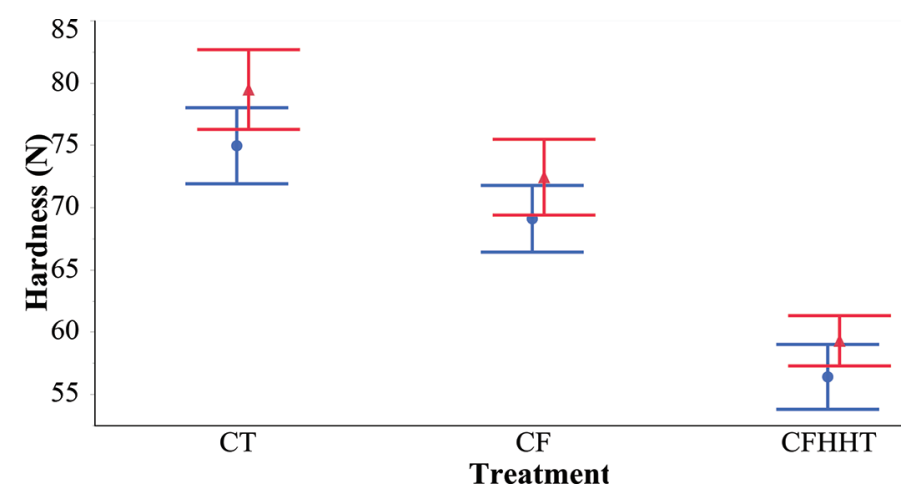

Figure 7. The effect of milk pretreatments on mean levels of hardness between $1(\bullet)$ and $11 \mathrm{~d}(\mathbf{\Delta})$ of ripening. Experimental cheese types were $\mathrm{CT}=$ control cheese, $\mathrm{CF}=$ cheese made from centrifuged milk, CFHHT $=$ cheese made from centrifuged milk containing highheat-treated centrifugate. Error bars show the SEM from 2 replicate trials. Color version available online. 
No significant effects of treatment on mean levels of cohesiveness, resilience, and springiness in the cheeses were observed (Table 3); however, the values for these texture parameters decreased $(P<0.05)$ between 1 and $11 \mathrm{~d}$ of ripening (data not shown). Although the exact reasons for this are unknown, this may be attributed to solubilization of colloidal calcium during the early stages of ripening (O'Mahony et al., 2005). O'Mahony et al. (2005) also observed rapid decrease in the value for springiness and cohesiveness of Cheddar cheese between 1 and $21 \mathrm{~d}$ of ripening. Levels of insoluble calcium were not determined in cheeses in the present study, and we suggest that this should be a focus for future studies in Maasdam-type cheese. We found no significant difference in the mean level of hardness of cheese between 1 and $11 \mathrm{~d}$ of ripening, contrary to the results obtained by O'Mahony et al. (2005), who observed rapid decrease in the texture value within first $21 \mathrm{~d}$ of ripening of Cheddar cheese; this discrepancy may be attributed to different cheese types and different manufacturing steps. We were unable to analyze the texture profile of cheese after $11 \mathrm{~d}$ of ripening due to eye formation.

\section{CONCLUSIONS}

We demonstrated the effect of centrifugation and incorporation of HHT centrifugate on the composition, texture, and ripening characteristics of Maasdam cheese. Interestingly, centrifugation of cheese milk before cheesemaking appeared to have minimal effect on composition and age-related changes on texture, $\mathrm{pH}$, proteolysis, and lactate levels of Maasdam cheese. However, incorporation of HHT centrifugate into cheese milk at levels of approximately 6 to $10 \%$ (wt/wt), depending on the protein content of centrifugate, into cheese milk significantly increased MNFS levels and also significantly decreased cheese hardness compared with control cheeses and cheeses made from centrifuged milk. Composition and strength of curd are considered important for eye-development characteristics of cheese without slits and cracks. In the current study, no clear trend for eye characteristics was observed between the treatments, and thus we were unable to draw a conclusion regarding the effect of the treatments applied on eye quality of cheese. We propose that this should be the focus of further research, possibly requiring analysis of a large number of commercial samples over the course of a manufacture season.

\section{ACKNOWLEDGMENTS}

This study was funded by the Dairy Levy Trust (Dublin, Ireland), Teagasc Walsh Fellowship program
(Oak Park, Carlow, Ireland), and in part by Ornua (Dubin, Ireland). Prabin Lamichhane is currently in receipt of a Teagasc Walsh Fellowship (RMIS6259). The authors acknowledge Juliet Wiley and Ram Raj Panthi for technical assistance with cheese trials, and Helen Slattery for carbohydrate and lactate analysis (all from Teagasc Food Research Centre, Moorepark, Fermoy, Co. Cork, Ireland). The authors also acknowledge Paula Reid (Teagasc Food Research Centre, Ashtown, Dublin, Ireland) for assistance with statistical analysis of the data.

\section{REFERENCES}

Agarwal, S., K. Sharma, B. G. Swanson, G. Ü. Yüksel, and S. Clark. 2006. Nonstarter lactic acid bacteria biofilms and calcium lactate crystals in Cheddar cheese. J. Dairy Sci. 89:1452-1466. https://doi .org/10.3168/jds.S0022-0302(06)72213-5.

Beresford, T. P., N. A. Fitzsimons, N. L. Brennan, and T. M. Cogan. 2001. Recent advances in cheese microbiology. Int. Dairy J. 11:259-274. https://doi.org/10.1016/S0958-6946(01)00056-5.

Chevanan, N., K. Muthukumarappan, P. Upreti, and L. E. Metzger. 2006. Effect of calcium and phosphorus, residual lactose and saltto-moisture ratio on textural properties of Cheddar cheese during ripening. J. Texture Stud. 37:711-730. https://doi.org/10.1111/j .1745-4603.2006.00080.x.

Daly, D. F. M., P. L. H. McSweeney, and J. J. Sheehan. 2010. Split defect and secondary fermentation in Swiss-type cheeses-A review. Dairy Sci. Technol. 90:3-26. https://doi.org/10.1051/dst/2009036.

Donato, L., and F. Guyomarc'h. 2009. Formation and properties of the whey protein/ $/$-casein complexes in heated skim milk-A review. Dairy Sci. Technol. 89:3-29. https://doi.org/10.1051/dst:2008033.

Engels, W. J. M., R. Dekker, C. de Jong, R. Neeter, and S. Visser. 1997. A comparative study of volatile compounds in the watersoluble fraction of various types of ripened cheese. Int. Dairy J. 7:255-263. https://doi.org/10.1016/S0958-6946(97)00003-4.

Exterkate, F. A., and A. C. Alting. 1995. The role of starter peptidases in the initial proteolytic events leading to amino acids in Gouda cheese. Int. Dairy J. 5:15-28. https://doi.org/10.1016/0958 -6946(94)P1596-6.

Fenelon, M. A., and T. P. Guinee. 2000. Primary proteolysis and textural changes during ripening in Cheddar cheeses manufactured to different fat contents. Int. Dairy J. 10:151-158. https://doi.org/10 .1016/S0958-6946(00)00040-6.

Garde, S., R. Arias, P. Gaya, and M. Nuñez. 2011. Occurrence of Clostridium spp. in ovine milk and Manchego cheese with late blowing defect: Identification and characterization of isolates. Int. Dairy J. 21:272-278. https://doi.org/10.1016/j.idairyj.2010.11.003.

Guinee, T. P., M. A. Fenelon, E. O. Mulholland, B. T. O'Kennedy, N. O'Brien, and W. J. Reville. 1998. The influence of milk pasteurization temperature and $\mathrm{pH}$ at curd milling on the composition, texture and maturation of reduced fat Cheddar cheese. Int. J. Dairy Technol. 51:1-10. https://doi.org/10.1111/j.1471-0307.1998 .tb02631.x.

Guinee, T. P., B. T. O'Kennedy, and P. M. Kelly. 2006. Effect of milk protein standardization using different methods on the composition and yields of Cheddar cheese. J. Dairy Sci. 89:468-482. https://doi.org/10.3168/jds.S0022-0302(06)72110-5.

Henneberry, S., M. Wilkinson, K. Kilcawley, P. Kelly, and T. Guinee. 2015. Interactive effects of salt and fat reduction on composition, rheology and functional properties of mozzarella-style cheese. Dairy Sci. Technol. 95:613-638.

Hou, J., P. L. H. McSweeney, T. P. Beresford, and T. P. Guinee. 2014. Effect of curd washing on the properties of reduced-calcium and standard-calcium Cheddar cheese. J. Dairy Sci. 97:5983-5999. https://doi.org/10.3168/jds.2014-8051. 
Huc, D., S. Challois, M. Monziols, C. Michon, and F. Mariette. 2014. Spatial characterisation of eye-growing kinetics in semi-hard cheeses with propionic acid fermentation. Int. Dairy J. 39:259-269. https://doi.org/10.1016/j.idairyj.2014.06.010.

IBM Corp. 2016. IBM SPSS Statistics for Windows, Version 24.0, IBM Corp., Armonk, NY.

Jean, K., M. Renan, M.-H. Famelart, and F. Guyomarc'h. 2006. Structure and surface properties of the serum heat-induced protein aggregates isolated from heated skim milk. Int. Dairy J. 16:303-315. https://doi.org/10.1016/j.idairyj.2005.04.001.

Johnson, M. E. 2017. A 100-year review: Cheese production and quality. J. Dairy Sci. 100:9952-9965. https://doi.org/10.3168/jds.2017 $-12979$.

Kelly, A. L., T. Huppertz, and J. J. Sheehan. 2008. Pre-treatment of cheese milk: Principles and developments. Dairy Sci. Technol. 88:549-572. https://doi.org/10.1051/dst:2008017.

Kelly, A. L., F. O'Flaherty, and P. F. Fox. 2006. Indigenous proteolytic enzymes in milk: A brief overview of the present state of knowledge. Int. Dairy J. 16:563-572. https://doi.org/10.1016/j.idairyj 2005.10.019

Kethireddipalli, P., and A. R. Hill. 2015. Rennet coagulation and cheesemaking properties of thermally processed milk: Overview and recent developments. J. Agric. Food Chem. 63:9389-9403. https:// doi.org/10.1021/jf504167v

Klijn, N., F. F. Nieuwenhof, J. D. Hoolwerf, C. B. van der Waals, and A. H. Weerkamp. 1995. Identification of Clostridium tyrobutyricum as the causative agent of late blowing in cheese by species-specific PCR amplification. Appl. Environ. Microbiol. 61:2919-2924.

Kosikowski, F. V., and V. V. Mistry. 1990. Microfiltration, ultrafiltration, and centrifugation separation and sterilization processes for improving milk and cheese quality. J. Dairy Sci. 73:1411-1419. https://doi.org/10.3168/jds.S0022-0302(90)78805-4.

Lamichhane, P., A. L. Kelly, and J. J. Sheehan. 2018a. Symposium review: Structure-function relationships in cheese. J. Dairy Sci 101:2692-2709. https://doi.org/10.3168/jds.2017-13386.

Lamichhane, P., A. Pietrzyk, C. Feehily, P. D. Cotter, D. T. Mannion, K. N. Kilcawley, A. L. Kelly, and J. J. Sheehan. 2018b. Effect of milk centrifugation and incorporation of high-heat-treated centrifugate on the microbial composition and levels of volatile organic compounds of Maasdam cheese. J. Dairy Sci. 101:5738-5750. https://doi.org/10.3168/jds.2017-14180.

Langeveld, L. P. M. 1971. Effect of the bactofugation of milk on the butyric acid fermentation in Gouda cheese. Neth. Milk Dairy J. $25: 11-18$

Lawrence, R. C., L. K. Creamer, and J. Gilles. 1987. Texture development during cheese ripening. J. Dairy Sci. 70:1748-1760. https:// doi.org/10.3168/jds.S0022-0302(87)80207-2.

Lawrence, R. C., J. Gilles, and L. K. Creamer. 1993. Cheddar cheese and related dry-salted cheese varieties. Pages 1-38 in Cheese: Chemistry, Physics and Microbiology. Vol. 2. P. F. Fox, ed. Springer US, Boston, MA

Le Bourhis, A.-G., J. Doré, J.-P. Carlier, J.-F. Chamba, M.-R. Popoff, and J.-L. Tholozan. 2007. Contribution of C. beijerinckii and $C$. sporogenes in association with $C$. tyrobutyricum to the butyric fermentation in Emmental type cheese. Int. J. Food Microbiol. 113:154-163. https://doi.org/10.1016/j.ijfoodmicro.2006.06.027.

Li, N., R. Richoux, M. Boutinaud, P. Martin, and V. Gagnaire. 2014 Role of somatic cells on dairy processes and products: A review. Dairy Sci. Technol. 94:517-538. https://doi.org/10.1007/s13594 -014-0176-3.

Li, N., R. Richoux, N. Leconte, C. Bevilacqua, M.-B. Maillard, S. Parayre, L. Aubert-Frogerais, J. Warlouzel, E. Moya-Leclair, C. Denis, P. Martin, and V. Gagnaire. 2017. Somatic cell recovery by microfiltration technologies: A novel strategy to study the actual impact of somatic cells on cheese matrix. Int. Dairy J. 65:5-13. https://doi.org/10.1016/j.idairyj.2016.09.003.

Lucey, J. A., and P. F. Fox. 1993. Importance of calcium and phosphate in cheese manufacture: A review. J. Dairy Sci. 76:1714-1724. https://doi.org/10.3168/jds.S0022-0302(93)77504-9.

Mateo, M. J., D. J. O'Callaghan, C. D. Everard, M. Castillo, F. A. Payne, and C. P. O'Donnell. 2010. Evaluation of on-line optical sensing techniques for monitoring curd moisture content and solids in whey during syneresis. Food Res. Int. 43:177-182. https://doi .org/10.1016/j.foodres.2009.09.023.

McCarthy, N. A., A. L. Kelly, J. A. O'Mahony, D. K. Hickey, V. Chaurin, and M. A. Fenelon. 2012. Effect of protein content on emulsion stability of a model infant formula. Int. Dairy J. 25:8086. https://doi.org/10.1016/j.idairyj.2012.03.003.

McSweeney, P. L. H. 2004. Biochemistry of cheese ripening. Int. J. Dairy Technol. 57:127-144. https://doi.org/10.1111/j.1471-0307 .2004.00147.x

Moynihan, A. C., S. Govindasamy-Lucey, M. Molitor, J. J. Jaeggi, M. E. Johnson, P. L. H. McSweeney, and J. A. Lucey. 2016. Effect of standardizing the lactose content of cheesemilk on the properties of low-moisture, part-skim Mozzarella cheese. J. Dairy Sci. 99:7791-7802. https://doi.org/10.3168/jds.2016-11215.

O'Mahony, J. A., J. A. Lucey, and P. L. H. McSweeney. 2005. Chymosin-mediated proteolysis, calcium solubilization, and texture development during the ripening of Cheddar cheese. J. Dairy Sci. 88:3101-3114. https://doi.org/10.3168/jds.S0022-0302(05)72992 $-1$.

O’Sullivan, D. J., P. L. H. McSweeney, P. D. Cotter, L. Giblin, and J. J. Sheehan. 2016. Compromised Lactobacillus helveticus starter activity in the presence of facultative heterofermentative Lactobacillus casei DPC6987 results in atypical eye formation in Swisstype cheese. J. Dairy Sci. 99:2625-2640. https://doi.org/10.3168/ jds.2015-10503.

Ong, L., R. R. Dagastine, M. A. E. Auty, S. E. Kentish, and S. L. Gras. 2011. Coagulation temperature affects the microstructure and composition of full fat Cheddar cheese. Dairy Sci. Technol. 91:739. https://doi.org/10.1007/s13594-011-0033-6.

Ong, L., R. R. Dagastine, S. E. Kentish, and S. L. Gras. 2012. The effect of $\mathrm{pH}$ at renneting on the microstructure, composition and texture of Cheddar cheese. Food Res. Int. 48:119-130. https://doi .org/10.1016/j.foodres.2012.02.020.

Panthi, R. R., K. N. Jordan, A. L. Kelly, and J. J. Sheehan. 2017. Selection and treatment of milk for cheesemaking. Pages 23-50 in Cheese: Chemistry, Physics \& Microbiology. P. L. H. McSweeney, P. F. Fox, P. D. Cotter, and D. W. Everett, ed. Academic Press, San Diego, CA

Pastorino, A. J., C. L. Hansen, and D. J. McMahon. 2003. Effect of pH on the chemical composition and structure-function relationships of Cheddar cheese. J. Dairy Sci. 86:2751-2760. https://doi.org/10 .3168/jds.S0022-0302(03)73871-5.

Patel, H. A., H. Singh, S. G. Anema, and L. K. Creamer. 2006. Effects of heat and high hydrostatic pressure treatments on disulfide bonding interchanges among the proteins in skim milk. J. Agric. Food Chem. 54:3409-3420. https://doi.org/10.1021/jf052834c.

Pearse, M. J., P. M. Linklater, R. J. Hall, and A. G. Mackinlay. 1985. Effect of heat induced interaction between $\beta$-lactoglobulin and $\kappa$-casein on syneresis. J. Dairy Res. 52:159-165. https://doi.org/10 $.1017 /$ S0022029900023980.

Rehn, U., F. K. Vogensen, S. E. Persson, K. Hallin Saedén, B. F. Nilsson, and Y. Ardö. 2011. Influence of microflora on texture and contents of amino acids, organic acids, and volatiles in semi-hard cheese made with DL-starter and propionibacteria. J. Dairy Sci 94:1098-1111. https://doi.org/10.3168/jds.2010-3146.

Rynne, N. M., T. P. Beresford, A. L. Kelly, and T. P. Guinee. 2004 Effect of milk pasteurization temperature and in situ whey protein denaturation on the composition, texture and heat-induced functionality of half-fat Cheddar cheese. Int. Dairy J. 14:989-1001. https://doi.org/10.1016/j.idairyj.2004.03.010.

Rynne, N. M., T. P. Beresford, A. L. Kelly, and T. P. Guinee. 2007. Effect of milk pasteurisation temperature on age-related changes in lactose metabolism, $\mathrm{pH}$ and the growth of non-starter lactic acid bacteria in half-fat Cheddar cheese. Food Chem. 100:375-382. https://doi.org/10.1016/j.foodchem.2005.09.062.

SAS Institute Inc. 2011. SAS/STAT 9.3 User's Guide. SAS Institute Inc., Cary, NC.

Shakeel-Ur-Rehman, D. Waldron, and P. F. Fox. 2004. Effect of modifying lactose concentration in cheese curd on proteolysis and in 
quality of Cheddar cheese. Int. Dairy J. 14:591-597. https://doi .org/10.1016/j.idairyj.2003.11.008.

Sheehan, J. J., M. A. Fenelon, M. G. Wilkinson, and P. L. H. McSweeney. 2007a. Effect of cook temperature on starter and non-starter lactic acid bacteria viability, cheese composition and ripening indices of a semi-hard cheese manufactured using thermophilic cultures. Int. Dairy J. 17:704-716. https://doi.org/10.1016/j.idairyj 2006.08.011.

Sheehan, J. J., J. C. Oliveira, A. L. Kelly, and P. L. H. McSweeney. 2007b. Effect of cook temperature on primary proteolysis and predicted residual chymosin activity of a semi-hard cheese manufactured using thermophilic cultures. Int. Dairy J. 17:826-834. https://doi.org/10.1016/j.idairyj.2006.08.012.

Sheehan, J. J., M. G. Wilkinson, and P. L. H. McSweeney. 2008. Influence of processing and ripening parameters on starter, non-starter and propionic acid bacteria and on the ripening characteristics of semi-hard cheeses. Int. Dairy J. 18:905-917. https://doi.org/10 1016/j.idairyj.2007.11.024

Su, Y.-C., and S. C. Ingham. 2000. Influence of milk centrifugation, brining and ripening conditions in preventing gas formation by Clostridium spp. in Gouda cheese. Int. J. Food Microbiol. 54:147154. https://doi.org/10.1016/S0168-1605(99)00199-3.

Te Giffel, M. C., and H. C. Van Der Horst. 2004. Comparison between bactofugation and microfiltration regarding efficiency of somatic cell and bacteria removal. Bull. Int. Dairy Fed. 389:49-53.

Thomsson, O., B. Ström-Holst, Y. Sjunnesson, and A.-S. Bergqvist. 2014. Validation of an enzyme-linked immunosorbent assay de- veloped for measuring cortisol concentration in human saliva and serum for its applicability to analyze cortisol in pig saliva. Acta Vet. Scand. 56:55. https://doi.org/10.1186/s13028-014-0055-1.

Van Hooydonk, A. C. M., P. G. De Koster, and I. J. Boerrigter. 1987. The renneting properties of heated milk. Neth. Milk Dairy J. $41: 3-18$.

Vasbinder, A. J., H. S. Rollema, and C. G. de Kruif. 2003. Impaired rennetability of heated milk; study of enzymatic hydrolysis and gelation kinetics. J. Dairy Sci. 86:1548-1555. https://doi.org/10 .3168/jds.S0022-0302(03)73740-0.

Walstra, P. H. J. M. Van Dijk, and T. J. Geurts. 1985. The syneresis of curd. 1. General considerations and literature review. Neth. Milk Dairy J. 39:209-246.

Waungana, A., H. Singh, and R. J. Bennett. 1996. Influence of denaturation and aggregation of $\beta$-lactoglobulin on rennet coagulation properties of skim milk and ultrafiltered milk. Food Res. Int. 29:715-721. https://doi.org/10.1016/S0963-9969(97)00011-2.

Wieking, W. 2004. Removal of somatic cells from raw milk by stateof-the-art centrifugal technology. Bull. Int. Dairy Fed. 389:45-47.

Yvon, M. and L. Rijnen. 2001. Cheese flavour formation by amino acid catabolism. Int. Dairy J. 11:185-201. https://doi.org/10 1016/S0958-6946(01)00049-8.

Zeppa, G., L. Conterno, and V. Gerbi. 2001. Determination of organic acids, sugars, diacetyl, and acetoin in cheese by high-performance liquid chromatography. J. Agric. Food Chem. 49:2722-2726. https://doi.org/10.1021/jf0009403. 